\title{
The Prediction of Allergic Proctocolitis by Using Hematological Parameters
}

\author{
Allerjik Proktokolit Öngörüsünde Hematolojik Parametrelerin Kullanımı
}

\author{
Sebahat ÇAM \\ (i) 0000-0001-7394-3569
}

İstanbul Medeniyet University School of Medicine Department of Pediatric Gastroenterology, İstanbul, Turkey

\begin{abstract}
Aim: Allergic proctocolitis (AP) is a common cause of rectal bleeding in infants. There is no diagnostic tool specific to the disease. The aim of the study was to evaluate hemogram parameters as a marker of inflammation in patients with AP.

Material and Methods: The files of patients who were exclusively breastfed and diagnosed as food protein induced AP were examined retrospectively. A hundred and fifty patients diagnosed with AP were included in the study. The same number of healthy babies formed the control group. Parameters in complete blood count were compared between patient and control groups. Rectosigmoidoscopic examination was performed to confirm the diagnosis in patients who could not achieve complete improvement with diet therapy, and hemogram parameters were evaluated according to eosinophilic infiltration in biopsies.

Results: The mean platelet volume (MPV) values $(p<0.001)$ and eosinophil percentages $(p=0.001)$ of the AP group were higher than the control group. The mean hemoglobin values of the AP group were statistically significantly lower than the control group $(\mathrm{p}<0.001)$. No statistically significant difference was found between patient and control groups in terms of white blood cell (WBC) count, platelet count, platelet distribution width (PDW) and neutrophil/lymphocyte ratio (NLR). WBC count, platelet count, hemoglobin, MPV and C-reactive protein (CRP) values were similar between groups of patients according to the number of eosinophils in colon biopsies.

Conclusion: We observed a significantly higher MPV values and eosinophil percentages in patients with AP. These parameters maybe helpful in diagnosis of AP.

Keywords: Allergy; proctocolitis; hemogram.
\end{abstract}

ÖZ

Amaç: Alerjik proktokolit (AP), bebeklerde görülen rektal kanamanın yaygın bir nedenidir. $\mathrm{Bu}$ hastalığa özgü olan bir tanı aracı yoktur. Çalışmanın amacı, AP tanısı konmuş olan hastalarda inflamasyonun bir belirteci olarak hemogram parametrelerini değerlendirmektir.

Gereç ve Yöntemler: Sadece anne sütü ile beslenen ve gida proteini kaynaklı AP tanısı konan hastaların dosyaları geriye dönük olarak incelendi. AP tanısı konulmuş olan 150 hasta çalışmaya dahil edildi. Aynı sayıda herhangi bir sağlık sorunu saptanmayan bebek ise kontrol grubunu oluşturdu. Tam kan sayımındaki parametreler hasta ve kontrol grupları arasında karşılaştırıldı. Diyet tedavisi ile tam iyileşme sağlayamayan hastalarda tanıyı doğrulamak için ilave rektosigmoidoskopik inceleme yapıldı ve hemogram parametreleri biyopsilerdeki eozinofil infiltrasyon düzeyleri dikkate alınarak değerlendirildi.

Bulgular: AP grubunun ortalama trombosit hacmi (mean platelet volume, MPV) değerleri $(\mathrm{p}<0.001)$ ve eozinofil yüzdeleri $(\mathrm{p}=0.001)$ kontrol grubundan daha yüksekti. AP grubunun ortalama hemoglobin değerleri kontrol grubundan istatistiksel olarak anlamlı derecede daha düşüktü $(\mathrm{p}<0.001)$. Hasta ve kontrol grupları arasında beyaz kan hücresi (white blood cell (WBC) sayısı, trombosit sayısı, trombosit dağılım genişliği (platelet distribution width, PDW) ve nötrofil/lenfosit oranı (NLR) açısından istatistiksel olarak anlamlı bir fark bulunmadı. WBC sayıs1, trombosit sayısı, hemoglobin, MPV ve C-reaktif protein (CRP) değerleri, kolon biyopsilerindeki eozinofil sayısına göre hasta grupları arasında benzerdi.

Received / Geliş Tarihi : 08.06.2020 Accepted / Kabul Tarihi : 12.08.2020 Available Online / Sonuç: AP'li hastalarda anlamlı olarak yüksek MPV değerleri ve eozinofil yüzdeleri gözlendi. Bu parametreler AP tanısında yardımcı olabilir.

Çevrimiçi Yayın Tarihi : 25.08.2020 Anahtar kelimeler: Allerji; proktokolit; hemogram. 


\section{INTRODUCTION}

Food protein-related allergic proctocolitis (AP) is a rather common cause of rectal bleeding in infants younger than 6 months old (1). It is mostly caused by cow's milk proteins, which pass into breast milk (2). Allergic reactions have been reported in approximately 0.5 to $1 \%$ of infants who exclusively breastfeed $(2,3)$. The diagnosis is usually made by clinical history and in response to the elimination diet. Excluding other diagnoses is essential. In babies undergoing rectosigmoidoscopic examination, eosinophilic infiltration is observed in colon epithelium, lamina propria, and muscularis mucosa $(4,5)$. Since there are no markers specific to the disease, it may be considered that complete blood count parameters such as white blood cell (WBC) count, platelet count, mean platelet volume (MPV) and eosinophil percentage can be used in the diagnosis and follow-up of inflammation. MPV has been recently studied as an inflammatory marker in various conditions, including ulcerative colitis, acute pancreatitis and myocardial infarction (6-8).

The aim of this study was to evaluate the hemoglobin, leukocyte and platelet parameters in the complete blood count in infants diagnosed with AP and also to investigate the relationship of these parameters with the severity of eosinophilic inflammation in patients undergoing rectosigmoidoscopic examination.

\section{MATERIAL AND METHODS}

The files of the patients who admitted to İstanbul Medeniyet University Faculty of Medicine Pediatric Gastroenterology Outpatient Clinic between January 2010 and January 2020, who were exclusively breastfed and diagnosed as food protein induced AP were examined retrospectively. Ethical approval was obtained from the İstanbul Medeniyet University Göztepe Training and Research Hospital Clinical Research Ethics Committee with the decision number 2020/0259 and dated 18.05.2020.

\section{Study Groups}

A hundred and fifty patients diagnosed with AP were included in the study. All of the babies were well, except for a history of bloody and/or mucous in stool. Patients who had no other infectious and inflammatory cause in etiology, and recovered in response to the elimination diet formed the study group. Patients older than 6 months, who had incomplete data in their files, who got complementary food or formulas, or who had another reason to explain rectal bleeding (infection, anal fissure, intussusception, volvulus, Hirschsprung's disease, necrotizing enterocolitis, inflammatory bowel disease, immune deficiency syndromes, hematological diseases), children with recent surgery and patients with signs of any chronic disease were excluded from the study. A hundred and fifty age and sex matched babies with nonspecific complaints who did not have any health problems in their physical and laboratory examinations or who admitted to a well-baby clinic for routine control and had a complete blood count were formed control group.

\section{Clinical Evaluation}

In our study, the diagnosis of AP was made with the history of the presence of blood and/or mucus in the stool, regression of symptoms with the removal of responsible foods from the mother's diet, recurrence of symptoms after the provocation test and no other reason to explain it. All complete blood count analyzes were performed in our hospital's hematology laboratory with an automatic analyzer. Rectosigmoidoscopic examination was performed in patients who did not get an adequate response despite the oligoantigenic diet to confirm the diagnosis and exclude other causes of rectal bleeding. After the cases were evaluated endoscopically (Fujinon EG/450PE5), biopsies were taken from the sigmoid colon and rectum. Biopsy samples were taken into formaldehyde, sent to the pathology laboratory, stained with hematoxylin-eosin and evaluated by a pathologist. The diagnosis of AP was confirmed in all cases with endoscopic appearance and pathological examination. The procedure was performed without sedation or colon preparation.

\section{Statistical Analysis}

SPSS v.24 program was used for statistical analysis. Categorical data are given as numbers and percentages, and numerical data are given as mean \pm standard deviation. Kolmogorov-Smirnov test was used to assess data normality. In comparison of numerical variables, Student's $t$ test was used to compare two groups, while ANOVA was used in more than two independent groups. Chi square test was used for categorical variables. A p value $<0.05$ was considered significant.

\section{RESULTS}

Of the babies who were diagnosed with AP, 72 (48.0\%) were girls and $78(52.0 \%)$ were boys. The mean ages of the patients and controls were $2.82 \pm 1.12$ and $2.78 \pm 1.13$ months, respectively. The demographic properties of the groups were similar (Table 1).

Time to see blood for the first time in stool was $9.3 \pm 1.7$ (range, 4-18) weeks. All patients received breast milk only. The general condition of all patients was good and their systemic examinations and growth-development values were within normal limits. Coagulation tests and stool examinations were normal in all cases.

No statistically significant difference was found between patients and controls in terms of WBC count $(\mathrm{p}=0.064)$, platelet count $(\mathrm{p}=0.230)$, platelet distribution width (PDW) $(\mathrm{p}=0.090)$ and neutrophil/lypmhocyte ratio (NLR) $(\mathrm{p}=0.778)$. These hematological parameters are shown in Table 2. The MPV values $(\mathrm{p}<0.001)$ and eosinophil percentages $(\mathrm{p}=0.001)$ of the AP group were statistically significantly higher than the control group. The mean hemoglobin values of the AP group were statistically significantly lower than the control group $(\mathrm{p}<0.001)$.

When endoscopy findings were evaluated in babies with AP, erythema, friability, lymphonodular hyperplasia and/or milimetric ulcers were detected in 138 babies, and nearly normal appearance was present in 12 babies. Histopathologically, more than 10 eosinophils were counted in per high power field (HPF) in lamina propria in 8 patients, compared to $6-10$ in 15 patients and below 6 in 7 patients. When patients were grouped according to the number of eosinophils in colon biopsies $(<6,6-10,>10$ eosinophils/HPF), WBC count, platelet count, hemoglobin, MPV and C-reactive protein (CRP) values were not different between the groups. Distribution of hemogram parameters according to eosinophil numbers in biopsies are shown in Table 3 . 


\section{DISCUSSION}

Food protein-related AP is characterized by inflammatory changes in the colon and rectum triggered by the intake of certain nutrient proteins through the gastrointestinal tract. In AP, inflammation rich in eosinophils occurs in the rectum (9). In this study, inflammatory markers detected in peripheral blood in infants with AP were evaluated as a non-specific indicator of inflammation and compared with healthy children. At the same time, the relationship between eosinophil counts in the rectum mucosa and hemogram parameters was evaluated in patients with AP. In the current trial, mean hemoglobin values were significantly lower in the AP group. Previous studies suggest that mild anemia may be present in patients with AP due to chronic blood loss (9-11). In this study, although the mean hemoglobin level in the AP group was lower than the control group, no severe anemia was detected in any case. This shows that in patients with AP, the loss of blood in the stool is very low, as observed in the clinic. Today, the easy-to-perform NLR is also used to measure systemic inflammation. The relationship of NLR with some diseases such as heart disease, chronic disease and Mediterranean fever has been shown in the literature (12-14). In their studies investigating NLR values in allergic rhinitis and asthma, Dogru et al. found higher NLR values compared

Table 1. Demographic characteristics of the groups

\begin{tabular}{lccc}
\hline & $\begin{array}{c}\text { AP } \\
(\mathbf{n = 1 5 0 )}\end{array}$ & $\begin{array}{c}\text { Control } \\
(\mathbf{n = 1 5 0})\end{array}$ & $\mathbf{p}$ \\
\hline Age (months), mean \pm SD & $2.82 \pm 1.12$ & $2.78 \pm 1.13$ & 0.760 \\
Gender, n (\%) & & & \\
$\quad$ Girl & $72(48.0 \%)$ & $74(49.3 \%)$ & 0.817 \\
$\quad$ Boy & $78(52.0 \%)$ & $76(50.7 \%)$ & \\
\hline AP: Allergic Proctocolitis, SD: Standard Deviation & &
\end{tabular}

Table 2. Comparison of hematological parameters between the control and study groups

\begin{tabular}{lccc}
\hline & $\begin{array}{c}\text { AP } \\
(\mathbf{n = 1 5 0})\end{array}$ & $\begin{array}{c}\text { Control } \\
(\mathbf{n = 1 5 0})\end{array}$ & $\mathbf{p}$ \\
\hline WBC count $\left(\times \mathbf{1 0}^{\mathbf{3}} / \boldsymbol{\mu L}\right)$ & $9.76 \pm 2.86$ & $9.59 \pm 3.02$ & 0.064 \\
NLR & $0.45 \pm 0.16$ & $0.45 \pm 0.17$ & 0.778 \\
Hemoglobin $(\mathbf{g} / \mathbf{d l})$ & $10.97 \pm 1.18$ & $11.13 \pm 1.30$ & $<\mathbf{0 . 0 0 1}$ \\
Platelet count $\left(\times \mathbf{1 0}^{3} / \boldsymbol{\mu L}\right)$ & $365.71 \pm 86.23$ & $360.12 \pm 78.46$ & 0.230 \\
MPV $(\mathbf{f l})$ & $9.07 \pm 0.78$ & $8.61 \pm 0.62$ & $<\mathbf{0 . 0 0 1}$ \\
PDW\% & $15.89 \pm 0.55$ & $15.72 \pm 0.51$ & 0.090 \\
Eosinophil percentage & $5.58 \pm 2.46$ & $5.18 \pm 1.90$ & $\mathbf{0 . 0 0 1}$ \\
\hline AP: Allergic Proctocolitis, WBC: White Blood Cell, NLR: Neutrophil/Lymphocyte
\end{tabular}

Ratio, MPV: Mean platelet volume, PDW: Platelet distribution width to the control group $(15,16)$. In our study, we did not find a difference between AP and control groups in terms of leukocyte counts and NLR values.

When it comes to platelet parameters, platelets have been shown to play a critical role not only in hemostasis, but also in the immune system and inflammation (17). Platelet indexes, including platelet count, MPV, PDW, and plateletcrit, are all markers of platelet activity. Increased MPV has been observed in many chronic, inflammatory and malignant diseases (17). Of particular concern to allergic inflammation is the observation that platelets express IgE receptors on their surface. Therefore, platelets from patients with allergic diseases can also respond to common allergens $(18,19)$. There are few studies investigating the role of inflammatory patterns in allergic events. We thought that MPV values might be useful in diagnosis, because AP is a chronic inflammatory disorder. In our study, we found that the average MPV level in children with AP was higher than the control. Similarly, Nacaroglu et al. (20) reported that MPV and plateletcrit are higher in children with AP and can be used to determine prognosis. As far as we know, there is no other study in the literature on this subject.

In other studies evaluating platelet indices in allergic events (such as atopic dermatitis, asthma), these indices have been shown to be used in diagnosis and follow-up. However, data on platelet indices on allergic diseases are controversial. Dogru et al. (21) reported that the MPV increased in children with asthma in their study. However, there are also studies showing that MPV is not different from healthy children in allergic airway diseases $(22,24)$. Topal et al. (25) showed that MPV values increased in patients with atopic eczema. In other studies, there was no significant difference between patients with atopic dermatitis and chronic urticaria and the control group in terms of MPV value (26).

In our study, we also evaluated the relationship between the severity of eosinophilic inflammation in mucosa and blood count parameters in patients undergoing rectoscopic examination. Although not an accepted standard criterion for the diagnosis of AP, eosinophilic infiltration is characteristic throughout the mucous layers, especially in lamina propria (27-30). Winter et al. (30) reported that more than 60 eosinophils per $10 \mathrm{HPF}$ in lamina propria strongly suggest AP. Eosinophils interspersed in crypts or in the muscularis mucosa are also highly associated with AP (31,32). In our study when peripheral blood parameters were evaluated according to the number of eosinophils in the mucosa, there was no significant difference between the cases.

Table 3. Hemogram parameters according to eosinophil numbers in biopsies

\begin{tabular}{lcccc}
\hline & $\begin{array}{c}<\mathbf{6} / \mathbf{H P F} \\
(\mathbf{n}=7)\end{array}$ & $\begin{array}{c}\mathbf{6 - 1 0} / \mathbf{H P F} \\
(\mathbf{n}=\mathbf{1 5})\end{array}$ & $\begin{array}{c}>\mathbf{1 0} / \mathbf{H P F} \\
(\mathbf{n}=\mathbf{8})\end{array}$ & $\mathbf{p}$ \\
\hline WBC count $\left(\times \mathbf{1 0}^{\mathbf{3}} / \boldsymbol{\mu L}\right)$ & $8.58 \pm 2.96$ & $10.36 \pm 3.04$ & $8.86 \pm 2.85$ & 0.333 \\
Hemoglobin $(\mathbf{g} / \mathbf{d l})$ & $11.41 \pm 1.04$ & $10.87 \pm 1.53$ & $11.21 \pm 0.85$ & 0.543 \\
Platelet count $\left(\times \mathbf{1 0}^{\mathbf{3}} / \boldsymbol{\mu L}\right)$ & $329.28 \pm 83.92$ & $395.80 \pm 92.26$ & $349.87 \pm 97.10$ & 0.248 \\
MPV $(\mathbf{f l})$ & $8.37 \pm 0.82$ & $8.89 \pm 1.06$ & $9.4 \pm 0.83$ & 0.096 \\
CRP $(\mathbf{m g} / \mathbf{L})$ & $0.31 \pm 0.07$ & $0.28 \pm 0.06$ & $0.34 \pm 0.05$ & 0.501 \\
\hline HPF: High Power Field, WBC: White Blood
\end{tabular}


In the literature, there is no study on the relationship between severity of inflammation in the colon and platelet parameters in patients with AP. When evaluating other diseases that cause inflammation in the colon, studies of inflammatory bowel disease generally found low MPV and high platelet counts. In some studies, platelet parameters have been associated with disease activity $(33,34)$. This adverse condition may be related to the severity of inflammation. Gasparyan et al. (35) assumed that, high-grade inflammatory diseases result in low levels of MPV, while low-grade inflammatory diseases have an adverse effect on MPV. In our study, when colon biopsies of patients undergoing rectosigmoidoscopy were evaluated according to eosinophilic infiltration, there was no significant relationship between eosinophil count and hemoglobin value, leukocyte and platelet parameters in biopsy samples.

The limitations of the study are that it is retrospective. Also, other colon inflammation markers such as calprotectin have not been studied.

\section{CONCLUSION}

In this retrospective clinical trial, we observed a significantly higher MPV values and eosinophil percentages in patients with AP. These hematological parameters may be used to predict AP. Further clinical trials with larger number of patients are required to reach a definitive result.

Conflict of Interest: There are no conflicts of interest.

\section{REFERENCES}

1. Lake AM. Food-induced eosinophilic proctocolitis. J Pediatr Gastroenetrol Nutr. 2000;30(Suppl):S58-60.

2. Maloney J, Nowak-Wegrzyn A. Educational clinical case series for pediatric allergy and immunology: allergic proctocolitis, food protein-induced enterocolitis syndrome and allergic eosinophilic gastroenteritis with protein-losing gastroenteropathy as manifestations of non-IgE-mediated cow's milk allergy. Pediatr Allergy Immunol. 2007;18(4):360-7.

3. Høst A, Husby S, Osterballe O. A prospective study of cow's milk allergy in exclusively breast-fed infants. Incidence, pathogenetic role of early inadvertent exposure to cow's milk formula, and characterization of bovine milk protein in human milk. Acta Paediatr Scand. 1988;77(5):663-70.

4. Machida HM, Catto Smith AG, Gall DG, Trevenen C, Scott RB. Allergic colitis in infancy: clinical and pathologic aspects. J Pediatr Gastroenterol Nutr. 1994;19(1):22-6.

5. Meyer R, Chebar Lozinsky A, Fleischer DM, Vieira MC, Du Toit G, Vandenplas Y, et al. Diagnosis and management of Non-IgE gastrointestinal allergies in breastfed infants-An EAACI Position Paper. Allergy. 2020;75(1):14-32.

6. Yüksel O, Helvaci K, Başar O, Köklü S, Caner S, Helvaci N, et al. An overlooked indicator of disease activity in ulcerative colitis: mean platelet volume. Platelets. 2009;20(4):277-81.

7. Endler G, Klimesch A, Sunder-Plassmann H, Schillinger M, Exner M, Mannhalter C, et al. Mean platelet volume is an independent risk factor for myocardial infarction but not for coronary artery disease. Br J Haematol. 2002;117(2):399-404.

8. Mimidis K, Papadopoulos V, Kotsianidis J, Filippou D, Spanoudakis E, Bourikas G, et al. Alterations of platelet function, number and indexes during acute pancreatitis. Pancreatology. 2004;4(1):22-7.

9. Nowak-Węgrzyn A. Food protein-induced enterocolitis syndrome and allergic proctocolitis. Allergy Asthma Proc. 2015;36(3):172-84.

10. Nowak-Wegrzyn A, Konstantinou G. Non-IgEmediated food allergy: FPIES. Curr Pediatr Rep. 2014;2:135-43.

11. Feuille E, Nowak-Węgrzyn A. Food protein-induced enterocolitis syndrome, allergic proctocolitis, and enteropathy. Curr Allergy Asthma Rep. 2015;15(8):50.

12. Tanındı A, Erkan AF, Ekici B, Alhan A, Töre HF. Neutrophil to lymphocyte ratio is associated with more extensive, severe and complex coronary artery disease and impaired myocardial perfusion. Turk Kardiyol Dern Ars. 2014;42(2):125-30.

13. Imtiaz F, Shafique K, Mirza SS, Ayoob Z, Vart P, Rao S. Neutrophil lymphocyte ratio as a measure of systemic inflammation in prevalent chronic diseases in Asian population. Int Arch Med. 2012;5(1):2.

14. Uslu AU, Deveci K, Korkmaz S, Aydin B, Senel S, Sancakdar E, et al. Is neutrophil/lymphocyte ratio associated with subclinical inflammation and amyloidosis in patients with familial Mediterranean fever? Biomed Res Int. 2013;2013:185317.

15. Dogru M, Evcimik MF, Cirik AA. Is neutrophillymphocyte ratio associated with the severity of allergic rhinitis in children? Eur Arch Otorhinolaryngol. 2016;273(10):3175-8.

16. Dogru M, Yesiltepe Mutlu RG. The evaluation of neutrophil-lymphocyte ratio in children with asthma. Allergol Immunopathol (Madr). 2016;44(4):292-6.

17. Franco AT, Corken A, Ware J. Platelets at the interface of thrombosis, inflammation, and cancer. Blood. 2015;126(5):582-8.

18. Joseph M, Capron A, Ameisen JC, Capron M, Vorng $\mathrm{H}$, Pancré $\mathrm{V}$, et al. The receptor for $\mathrm{IgE}$ on blood platelets. Eur J Immunol. 1986;16(3):306-12.

19. Capron M, Joseph M. The low affinity receptor for IgE on eosinophils and platelets. Monogr Allergy. 1991;29:63-75.

20. Nacaroglu HT, Bahceci Erdem S, Durgun E, Karaman S, Erdur CB, Unsal Karkmer CS, et al. Markers of inflammation and tolerance development in allergic proctocolitis. Arch Argent Pediatr. 2018;116(1):e1-7.

21. Dogru M, Aktas A, Ozturkmen S. Mean platelet volume increased in children with asthma. Pediatr Allergy Immunol. 2015;26(8):823-6.

22. Akgedik R, Yağız Y. Is decreased mean platelet volume in allergic airway diseases associated with extent of the inflammation area? Am J Med Sci. 2017;354(1):33-8.

23. Batmaz SB. Simple markers for systemic inflammation in pediatric atopic dermatitis patients. Indian $\mathbf{J}$ Dermatol. 2018;63(4):305-10.

24. Nacaroglu HT, Isguder R, Bahceci SE, Ceylan G, Korkmaz HA, Karaman S, et al. Can mean platelet volume be used as a biomarker for asthma? Postepy Dermatol Alergol. 2016;33(3):182-7. 
25. Topal E, Celiksoy MH, Catal F, Karakoç HTE, Karadağ A, Sancak R. The platelet parameters as inflammatory markers in preschool children with atopic eczema. Clin Lab. 2015;61(5-6):493-6.

26. Kasperska-Zając A, Grzanka A, Jarzab J, Misiołek M, Wyszyńska-Chłap M, Kasperski $J$, et al. The association between platelet count and acute phase response in chronic spontaneous urticaria. Biomed Res Int. 2014;2014:650913.

27. Jenkins HR, Pincott JR, Soothill JF, Milla PJ, Harries JT. Food allergy: the major cause of infantile colitis. Arch Dis Child. 1984;59(4):326-9.

28. Hill SM, Milla PJ. Colitis caused by food allergy in infants. Arch Dis Child. 1990;65(1):132-3.

29. Lake AM, Whitington PF, Hamilton SR. Dietary protein-induced colitis in breast-fed infants. J Pediatr. 1982;101(6):906-10.

30. Winter HS, Antonioli DA, Fukagawa N, Marcial M, Goldman H. Allergy-related proctocolitis in infants: diagnostic usefulness of rectal biopsy. Mod Pathol.
1990;3(1):5-10.

31. Goldman H, Proujansky R. Allergic proctitis and gastroenteritis in children. Clinical and mucosal biopsy features in 53 cases. Am J Surg Pathol. 1986;10(2):75-86.

32. Odze RD, Bines J, Leichtner AM, Goldman H, Antonioli DA. Allergic proctocolitis in infants: a prospective clinicopathologic biopsy study. Hum Pathol. 1993;24(6):668-74.

33. Kapsoritakis, AN, Koukourakis MI, Sfiridaki A, Potamianos SP, Kosmadaki MG, Koutroubaki IE, et al. Mean platelet volume: a useful marker of inflammatory bowel disease activity. Am J Gastroenterol. 2001;96(3):776-81.

34. Öztürk, ZA, Dag MS, Kuyumcu ME, Cam H, Yesil Y, Yilmaz N, et al. Could platelet indices be new biomarkers for inflammatory bowel diseases? Eur Rev Med Pharmacol Sci. 2013;17(3):334-41.

35. Gasparyan AY, Ayvazyan L, Mikhailidis DP, Kitas GD. Mean platelet volume: a link between thrombosis and inflammation? Curr Pharm Des. 2011;17(1):47-58. 